\begin{tabular}{|c|c|c|}
\hline Received 23.12.2021 & \multirow{3}{*}{ Research Article } & \multirow{3}{*}{$\begin{array}{c}\text { JOTS } \\
6 / 1 \\
\text { 2022: } 85-110\end{array}$} \\
\hline Accepted 31.12.2021 & & \\
\hline Published 01.01.2022 & & \\
\hline
\end{tabular}

\title{
Additional Turkic and Tungusic Borrowings into Yukaghir VI
}

Yukagir Dilindeki Türkçe ve Tunguzca Alintılara İlaveler VI

\author{
Peter PIISPANEN ${ }^{*}$ \\ Stockholm University (Stockholm/Sweden) \\ E-mail: peter.piispanen@finska.su.se
}

In this sixth part of this paper series, additional Turkic (i.e. Yakut) and Tungusic (i.e. Ewen or Ewenki) lexical borrowings into the Yukaghir languages and dialects are presented and evaluated in semantic, phonological and other considerations and viewpoints, thus providing loanword etymologies. In summary, a total of fourteen Yakut borrowings, four Tungusic and three Russian borrowings are given. An extra section of interest deals in the etymologizing of up until now quite mysteriously named Yukaghir child and youth games, and lastly some etymological notes and documentation corrections are again given.

Key Words: Lexical borrowing, Tungusic, Turkic, Mongolic, Yukaghir, Russian.

\footnotetext{
ORCID ID: 0000-0003-4398-2107.
} 


\section{ग(৫)}

\section{Introduction}

This paper series (thus far: Piispanen 2018, 2019a, 2019b, 2020a, 2020b) continues the presentation and argumentation of newly discovered Turkic and Tungusic (and Russian) lexical borrowings into the Yukaghir languages of the far northeastern Siberia, preceded by a topic section of interest like in the other parts of this series. Direct Mongolic borrowings into the Yukaghir languages and dialects, mentioned in previous parts of this paper series, is a large topic of its own and will be presented in a separate, future paper likely outside of this paper series.

In the so-called special sections of each paper in the series, I have taken the opportunity to highlight various points or topics of interest in Yukaghir studies. These topics are meant to stimulate additional Yukaghir studies, clarify, rectify or correct older documents, discuss grammar, etymologize additional materials and more. In 2018 (Part I), the phonology and Yukaghir borrowings into the surrounding languages were generally evaluated. In 2019a (Part II), the Altaic language hypothesis and chronological theories were discussed, and then in $2019 b$ (Part III), a two-parter double-paper, corrections to older Yukaghir documentation (on Chuvan, and Omok and Spiridonov's dialectal Kolyma Yukaghir materials) as well as borrowed grammatical markers were presented (in the first half), and, further, the concept of Para-Yukaghir languages was touched upon briefly (in the second half). In 2020a (Part IV), the nominal derivational suffix *-jo was discussed, while in 2020 b (Part V), the etymology of Yukaghir toponymical terms were discussed in detailed analysis based on previous and new research. In this part, the extra topic section deals in etymologies of various Yukaghir child and youth games, most of which have never before been properly etymologized. ${ }^{1}$

\section{Yukaghir game etymologies}

Various social activities and games among the Yukaghirs were described by Jochelson (1926: 126-130). Some games are also described elsewhere in other

1 I wish to thank my colleagues Mikhail Zhivlov, Juho Pystynen, Robert Lindsay, Benjamin Brosig, Ümüt Çınar, Marcel Erdal, Alexander Savelyev, Vener Akhmetov and Jörg Bäcker for their very valuable and useful input on an earlier draft version of this paper through personal communication ( $p c)$. All remaining errors are, of course, my own. 
historical documents. The specifics of the activities are well described and several of the games mirror those found played among other children in the world and among neighboring populations. In this section, the names of several different Yukaghir child games are etymologized for the first time. These games were no doubt great socially bonding activities and good practice for the real hunt.

KD xaxadieñonut-lod'ol 'grandfather game' (Jochelson, 1926: 128). In this game, the mother, with her children holding on to one another in a file behind her, tries to protect them against the attacks of a mythical 'grandfathercannibal'. Since the word for 'grandfather' is often used in a taboo fashion as a synonym for 'bear', one may wonder if the cannibal is nothing more than a bloodthirsty bear. Said bear could then also be symbolic for the human shaman who, as was commonly believed had turned into a bear form, be a cannibal devouring other humans. In any case, the latter succeeds in catching the children, one after another, then fights the mother herself and conquers her. I note that this play relatively closely mirrors a particular folkloric Yukaghir tale, which must be its inspiration, and as Jochelson (1926: 128) points out this game also plays out the same way as the so-called Raven game of the Koryaks (Jochelson, 1908: 780). This etymology has to the best of my knowledge not been discussed before, but the originator of the KD form can be reconstructed as *qajqaj-de:-nonu- $\delta(-l ' o: \delta a-l)$ 'lit. grandfather wolf (game)', that is grandfatherdiminutive-wolf-nominal marker-game-marker.

KD neniñčil-lod'ol 'mutual-fight game'. The name of this male-only game

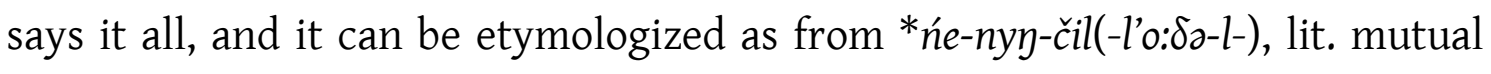
fight game, segmented as reciprocal marker-to fight-marker-game-marker. The word for the verb 'to fight' used here, however, is a Tungusic borrowings, cf. TU *yen- 'to attack, to fight' (EDAL 1027).

KD čebelge-menmegel-lod'ol 'field-jumping game'. In this male-only game the participants jump over a bent stick, the ends of which are held, one in each hand, like a rope. This game name literally means valley jump(-game), and it can be

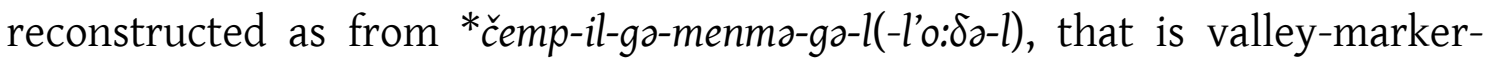
marker-to jump-marker-marker-game-marker. 
The following three are mentioned in Nikolaeva (2016: 107, 241, 322, respectively), but the etymologies are and remain, as far as I can tell, unknown: $\mathrm{KD}$ andajal-lod'ol 'competitive archery game'; ${ }^{2} \mathrm{KD}$ leptule-lod'ol 'ball game' ${ }^{3}$ (le'ptule-lo'dol according to Jochelson, 1926); KD oyeñie-lod'ol 'stride game'.

The first one, KD andajal-lod'ol is difficult to etymologize, but the name may be composed of the element KY and'a 'eye' + aja 'arbalest; arrow', i.e. as

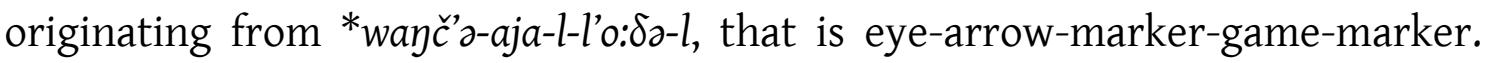
Alas, I am unable to etymogize the second one, KD leptule-lod'ol 'ball game', as the first word does not otherwise appear to exist in Yukaghir.

Let us attempt to etymologize the last of these three: KD oyeñie-lod'ol 'stride game' (also KY öjunge: 'traditional game (jumping through hurdles or jumping on one foot)'; KJ ojeyie). In this game, a given distance must be traversed in the least possible number of steps, and the male-only participants are also permitted to jump. This KD game can be reconstructed as from *öjeykə-l'o: $\delta$ ə-l, lit. hare game, cf. TY öjege 'hare'. Nikolaeva (2006: 322) reconstructs *öjeyka 'hare' based only on Tundra Yukaghir vocabulary, but the root is, as shown here, seemingly found also in the Kolyma Yukaghir game name, suggesting that this particular word for 'hare' goes back to Late Proto-Yukaghir. This suggestion has phonological problems, however, because /*nk/ would not ordinarily yield / $\mathrm{y} /$ in $\mathrm{KY}$. One might tentatively posit *öjuy - (the base root used in KY) > *öjuyə-gə (suffixed form used in TY, -go is a nominal derivational suffix as per Nikolaeva, 2006: 80) > *öjenge: (reconstructed form based on TY data, but *ojunge: based on KY data).

The sign $\breve{\jmath}$ used in Jochelson's texts represent the modern transcription d'. Hence, Nikolaeva (2006: 108) transcribes this word as and'ad'al-l'odol 'competitive archery game'. Note the comparison to Yakut aja 'arbalest; arrow' (TMS 120 ), which could be one of the segments of this Yukaghir game name. The name could hardly be related to antajal 'sorcery, witchcraft'. In this male-only game, the contestants shoot off an arrow from a game bow and the winner is the one who shot the arrow the furthest distance.

3 According to Jochelson there used to be soccer-like ball game played among Yukaghirs, Koryaks, Chukchee and Eskimos in ancient times. However, during his visit in the 1920s only another type of ball game was played among Yukaghirs. Girls and boys would sit down in a circle on the ground. One player throws a heavy ball into the circle and the participants try to catch it. The one catching it has the right to hit the knees of any he pleases with the ball. Old love-accounts were settled this way, as getting hit by the ball was rather painful. After a few throws the winner threw the ball back into the circle and the game began anew. 


\section{ग(৫)}

Further, the following games from Jochelson (1926) were for some reason not mentioned in Nikolaeva's dictionary and are therefore to the best of my knowledge non-etymologized: KD nekieyil-lod'ol 'common-run game'; KD meluncāle-lod'ol 'chest-tree game', lit. chest-drop-game?; KD añjedaibilel-lod'ol 'with-closed-eyes-game'.

The first one, KD nekieyil-lod'ol 'common-run game' is a mini marathongame where the male-only contestants run over a stretch of four to five miles to an appointed place, with the winner being the first one to reach the goal and thereupon winning a significant prize (what types of prizes were awarded would indeed be interesting to know, but I lack such information). During winter-time the marathon is ran using snow shoes over an even greater distance through soft and hard snow and over the ice of frozen rivers! The name can be etymologized as simply from *no-kij-il-l'o:סz-l-, that is: reciprocal marker-two-marker-gamemarker, cf. KY ń-kiji:- 'to compete (in running)'; TY ń-giejitče 'competition (in running); running reindeer (lit. overtaking each other).

In the second one, KD meluncāle-lod'ol, a row of girls opposite a row of boys lift a heavy log with their hands, press it against their chest and try to throw the opposite row to the ground. When one row begins to yield, old men and women come to their aid. In the end, the losing party falls to the ground squashed rather

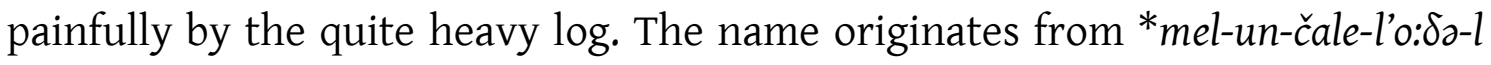
which, as far as I can tell, which literally means chest-genitive marker-rapid drop-game.

The third one, KD añjedaibilel-lod'ol 'with-closed-eyes-game' is, according to Jochelson (1926: 128) played like blind man's bluff. The game idea could have been borrowed from the Russians, but among the Yukaghirs a twist is the creation of two teams, one of boys, and one of girls, which is common among their games. A blind-folded boy catches only girls, and vice versa. It can be

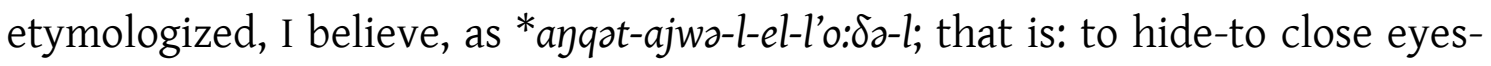
marker-marker-game-marker, cf. KY ayitz- 'to hide, to conceal (TR)' even though there are some phonological irregularities.

Additionally, Jochelson (1926: 129) also mentions the me'mečeñonul-lo'dol

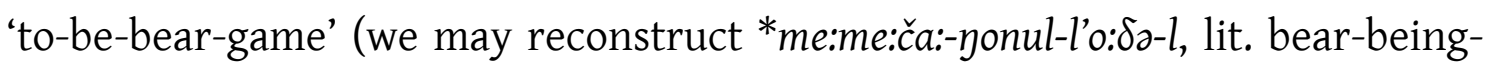
game-marker) and the tolo'uñonul-lo'dol 'to-be-wild-reindeer-game' (< *tolowz- 


\section{ग(৫)}

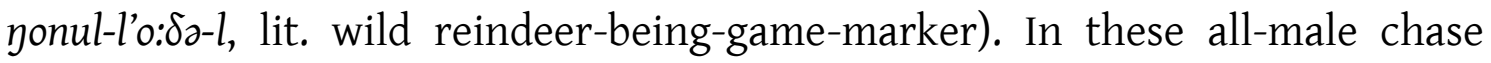
games the actual hunt for a bear or reindeer, respectively, are mimicked. One greatly skilled participant, running around on all fours is hunted by the others; the hunted attempts to avoid dull wooden arrows shot by the participants, but is eventually "killed" by the participants.

\section{New Turkic borrowings into Yukaghir}

In this section, six new Turkic (i.e. Yakut) borrowings into the Yukaghir languages are described, along eight tentative ones, a few of them being originally Russian words transmitted through Yakut. In order to bolster the idea about the direction of borrowing being Yakut > Yukaghir I have attempted to also find Dolgan forms of the same, but have unfortunately not been able to find such for any of the borrowings suggested in this section.

New borrowing

Russian pogón (pe'gon) 'погон = (shoulder) strap', borrowed as Yakut pogon 'погон = (shoulder) strap' (JRS 296), borrowed as: MK aatschen-pógon 'bridle, lit. reindeer’s strap' (Nikolaeva, 2006: 354).

This very early documented Yukaghir compound consists of a native word and a borrowing. The compound can be segmented as áatsche-n-pogon, or, in modern parlance a:čə-n-pogon, meaning exactly reindeer + genitive marker + strap. The original Russian word pogón has several meanings, including shoulder insignia or epaulet, a belt for carrying something over one's shoulders (for example: the strap of a hunting rifle), a product of the primary distillation vapors of oil, poor vodka of poor quality obtained at the end of the distillation process, or a device in a mechanism which moves or slides something. Semantically, a bridle, that is a mouth piece (of a reindeer), can then be equated with a placed strap or a sliding mouth device. The borrowed word may have originated in either Russian or Yakut, as there are no distinguishing phonological marks to differ between these two options, but given that much of the Yukaghir reindeer-related terminology is borrowed from Yakut, this word was likely also borrowed therefrom instead of directly from Russian. The word has seemingly not been borrowed into Ewen or Ewenki.

New borrowing

Russian porox ('porəx) 'порох = (gun)powder', borrowed as Yakut buorax ' $п о р о \mathrm{x}=$ (gun)powder' (JRS 85), borrowed as: TY puorax 'порох = (gun)powder' (Kurilov, 2001: 338). 
Not unexpectedly, the word for the trading commodity of 'gunpowder' was borrowed into Yukaghir either from Russian or Yakut. While not having an individual dictionary entry - and therefore tricky to find - the Yukaghir word is found in inflected form in an example sentence: Ol'il... xabun puoraxek mentemey monyudaya, maarxan saadiek kuderetemle = ольил... когда спросят, сколько пороха возьмешь, положит одну палочку. The Russian word is pronounced with stress on the first syllable and a reduced vowel in the second syllable; the expected outcome of this in Yukaghir is indeed puorax. However, the Yakut form, also borrowed from Russian, and accustomed to Yakut prosodic structure, is buorax, which devoiced is also identical to Yukaghir puorax. Both the Yakut and Russian forms end in $-\chi$, which has seemingly been retained in the Yukaghir form instead of becoming $-k$ or $-q$ (Piispanen, 2019c: 226), although this is unclear because in Kurilov's orthography $<x>$ represents the two allophones of /q/, namely $/ \mathrm{q} / \sim / \mathrm{x} /$. Therefore, it is impossible in this case to determine the exact donor language, Russian or Yakut, but the word is in any case ultimately of Russian etymology. This is yet another cultural borrowing into Yukaghir due to trading activities; the borrowing of Russian nopox 'gunpowder' into Yakut, Ewen and Ewenki has already been mentioned elsewhere (Piispanen, 2019c: 228).

New borrowing

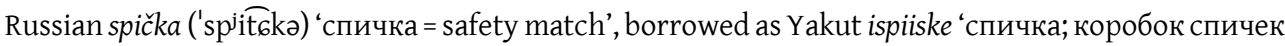
= safety match; matchbox' (JRS 155), borrowed as: TY ispiiske 'safety match' (Kurilov, 2001: 439).

The word for 'matches', another trading commodity, was borrowed from Yakut into Yukaghir, as evident from the phonology, all of which is in accordance with Yakut prosody. The word is etymologically, however, ultimately of Russian origin. The Yukaghir word is not found as a dictionary entry, however, but instead is included in inflected form in an example sentence: Tet l'ienulaxaney anme ispiiskeley siezajl = когда так сидели (в темноте), вдруг чиркнула спичка. The Russian borrowing in Yakut and Ewenki has already been discussed elsewhere.

New borrowing

Yakut ńamygyraa- 'быстро чавкать, проворно жевать, быстро двигать челюстями; говорить очень быстро и невнятно = to slurp fast, to chew cheerfully, to move jaws fast; to speak very fast and slurred' (JRS 259), borrowed as, or from: TY ńатуе- 'чавкать = to slurp' (Kurilov, 2001: 306); KY ńатуд- 'чавкать = to slurp, to eat noisily'; KK ńamza- 'id.'. 
The Yakut word appears to be, considering the geographic spread, an old borrowing, unless it is actually instead a Yukaghir borrowing into Yakut, because the etymology of the Yakut word is as far as I can tell not known (the word is not found in Dolgan so no Common Yakut form can be posited). The word as such does not appear in northern Tungusic and this is based on both the semantics and phonology a secure borrowing between Yakut and Yukaghir regardless of the direction of borrowing.

New/Corrected borrowing

Yakut xoroj 'олень самец на втором году = two-year old male reindeer' (Ugarov, 1993: 84), borrowed as: KY qoroj 'two-year old male reindeer' (Nikolaeva, 2006: 388).

The KY word has previously been suggested, back in the first part of this paper series, a borrowing from a Chukchee-Koryak language, cf. ProtoChukchee-Koryak *qorá-ya 'domesticated reindeer' (Piispanen, 2018: 131-132), but new data shows that this cannot be correct. While a connection between the two is still possible through ancient borrowing, a much better comparison, and likely direct donor language for the Kolyma Yukaghir form is Yakut xoroj, of identical semantics and phonology (we may assume regular Pre-Yakut *qoroj). Therefore, the KY word was borrowed directly from Yakut instead, but given the similarity with the Chukchee-Koryak forms, it is possible that Yakut had borrowed this word from there in the first place. Due to semantic and phonological differences such a thesis is uncertain, however, but if correct we may posit a borrowing chain of: Chukchee-Koryak > Yakut > Yukaghir.

New borrowing

Yakut kyčytar 'двухгодовалая самка оленя = two-year-old female reindeer' (Makarov, 1974; Petrov, 2015), borrowed as KY kiť̌a: 'two-year old reindeer female' (Nikolaeva, 2006: 213).

The Kolyma Yukaghir reindeer-related word is, not unexpectedly, another secure Yakut borrowing. We can posit the double assimilation *kyčytar > *kyčta: > kičta: > KY kiťca:, which explains both the consonant cluster in Yukaghir as well as the long final vowel.

Tentative borrowing

Yakut ogo kuottar 'делать выкидыш = to have a miscarriage', kuottaryy 'выкидыш = miscarriage' (JRS 190), borrowed as: TY kutuoj 'miscarriage (of a female reindeer)', kutuo'сделать выкидыш (об олене) = to have a miscarriage (of a reindeer)'; TD -kutoi 'miscarriage (of reindeer or woman)' (Nikolaeva, 2006: 230; Kurilov, 2001: 174). 
This appears to be another reindeer-related Yakut borrowing into a Yukaghir dialect, but the suggestion has some phonological problems. While degemination is expected in Yukaghir, the vocalism is only explainable by progressive vowel assimilation in the borrowed form and this is not very common. Semantically, the meanings are of course identical.

Tentative borrowing

Yakut bügülex bügüjex 'овод = warble fly, botfly, gadfly' (Makarov, 1974), borrowed as: TY pugučie 'black fly (Simuliidae)' (Nikoleava, 2006: m367).

This isolated TY word for 'black fly' appears to have been borrowed from Yakut; the ending is a typical suffix of nomina, and if the hypothesis is correct then the bare root of the Yakut word was borrowed *bügü- > pugu- and then suffixed. Thus, the TY word is not cognate with the Uralic word for 'black' as has been suggested elsewhere (Piispanen, 2013: 187).

Tentative borrowing

Yakut ogo kuottar 'делать выкидыш = to have a miscarriage', kuottaryy 'выкидыш = miscarriage' (JRS 190), borrowed as: TY kutuoj 'miscarriage (of a female reindeer)', kutuo- 'сделать выкидыш (об олене) = to have a miscarriage (of a reindeer)'; TD -kutoi 'miscarriage (of reindeer or woman)' (Nikolaeva, 2006: 230; Kurilov, 2001: 174).

This appears to be another reindeer-related Yakut borrowing into a Yukaghir dialect, but the suggestion has some phonological problems. While degemination is expected in Yukaghir, the vocalism is only explainable by progressive vowel assimilation in the borrowed form and this is not very common. Semantically, the meanings are of course identical.

Tentative borrowing

Yakut nonoi 'грубый, упрямый; небольшого роста = small stature; rude, stubborn' (Pekarsky, 1959:

1752), borrowed as TY nonodu- 'to catch with bad intentions (TR)' (Nikolaeva, 2006: 309).

This modern dialectal Yukaghir form is only attested as one singular verbal form, and it is another Yakut borrowing. The ending of $-d u$ is found with several transitive verbs in Yukaghir.

Tentative borrowing

Yakut ńoyor 'название маленькой рыбы в якутск и вилюйск = name of a small fish in Yakutsk and Vilyuisk (Coregonus lugun, a species of salmon)' (Pekarsky, 1959: 1728), borrowed as TD nogien 'a kind of salmon found in a lake' (Nikolaeva, 2006: 305).

This is another Yakut borrowing only into dialectal Yukaghir. In Yukaghir, the word-end is marked by the emphatic marker $-\eta$, commonly found, for 
example, in the lexical Yukaghir documentation of Spiridonov (2003). Phonologically, the TD - $g$ - goes back to - $\gamma$-, which came with the borrowing. The phonological overlap is therefore good except for the Yukaghir diphthong (it could be considered affective) as well as the loss of the word-initial palatalized sonorant which has become depalatalized, both of which remain unexplained.

Tentative borrowing

Proto-Turkic čar 'whetstone', etc. (VEWT 99-100, Yegorov, 1964: 221, Fedotov, 1996: 143) > Yakut sardaya sardāna 'short heavy arrow with a broad head', borrowed as KY čarcaqa:n 'a man in folklore'; KK t'art'eqan; TK t'a:rt'eqan (Nikolaeva, 2006: 126).

Based on this comparison, it would seem as if a man's name in a story of Kolyma Yukaghir folklore means 'heavy arrow', which is a fitting nickname for a legendary warrior or fighter, perhaps through a story originally told by the Yakut. Phonologically, the comparison is fairly accurate. The Yukaghir name bears a Tungusic suffix and phonological leveling of the name seems to have occurred, perhaps to accommodate storytelling prosody. All of this is merely hypothetical, however, as we have no information about the story at hand to check any facts.

Despite a suggestion by Erdal, Persian čarx 'wheel', cannot be the direct source of the various Turkic (and subsequently Yukaghir) forms. Rather, A. Savelyev has aptly demonstrated that Early Bulgharic *čar-la- $\gamma$ 'sickle' (borrowed as Hungarian sarló) resulted in Chuvash sorla 'sickle', ${ }^{4}$ which is derived from Turkic *čar-la- 'to whet', from a Proto-Turkic root *čar- (found in numerous languages according to the references). Any classical Persian - $a$ - would normally have been found as $-a$ - also in Chuvash (through Old Chuvash *ä), while here we instead have Chuvash -o-/-u- from old Chuvash *a. The change of $\check{c}>\check{s}$ in Hungarian is very old and considered a hallmark of the earliest loans from Bulghar Turkic. Interestingly, J. Pystynen notes the existence of a front-voweled form in Udmurt šer 'whetstone', šery- 'to whet', but its connection, if any, to the Turkic forms is unclear. Savelyev suggests that the old Bulgharic form of sickle was borrowed into Proto-Permic, yielding Komi-Zyrian ćarla 'sickle', long before any contacts with Middle Turkic, while the inherited Udmurt form must have been replaced by surlo 'sickle' due to contact with the northeastern Chuvash

4 Räsänen, in VEWT 100, mentions this Chuvash form for sickle as the only reflex of *čar-la- $\gamma^{-}$, perhaps making it specifically West Turkic, whereas the only known form resulting from Middle Turkic (according to Róna-Tas \& Berta) is Chagatai čarla- 'to whet'. 
groups (the so-called чюваша арская) during the $14^{\text {th }}-17^{\text {th }}$ centuries. PostMongolic contacts with Volga Kipchak dialects would have resulted in an expected $c^{-}$, and different Permic vowels, but this is not demonstrated, suggesting that Savelyev's excellent analysis above is the correct one.

Tentative borrowing

Yakut tatyr 'ступающий неровно, как бы прихрамывая (о лошади) = stepping unevenly, as if limping (about a horse) (JRS 380), borrowed as: TY tatuor 'a man in folklore', tatuorkaan, tatuorńikaan amaa, táuorkaanap (Nikolaeva, 2006: 426).

This appears to represent another folklore borrowing from Yakut into Tundra Yukaghir. Despite some Yukaghir forms bearing the Tungusic diminutive suffix -kaan, these words do not appear to be attested at all in Ewen or Ewenki, the prospective donor languages into Yukaghir. The diphthong in Yukaghir appears to be a typical Yakut feature, but strangely enough the Yakut form is not a diphthong. Perhaps the protagonist was a limping Yakut, and the story reached the Yukaghir by way of the Tungusic, where it is no longer attested, but without knowing the details of the story none of these details can be verified and this remains a tentative suggestion.

Tentative borrowing

Yakut čazar 'семья; дети; прислуга, Челядь, слуги = family; children; maid, servant' (JRS 507), borrowed as KY čayaa 'a dog's name' (Nikolaeva, 2006: 126).

The Yakut word is of clear Turkic etymology, as informed by V. Akhmetov, cf. Common Turkic *č̄̄ka 'new-born child', as attested in numerous languages, including Turkmen chaga 'child'; Tatar (bala-)chaga '(young) child'; Kyrgyz \& Uyghur bala-čaga 'children'; Noghai bala-šapa 'children'; Old Ottoman Turkish (14 ${ }^{\text {th }}$ century) čaya 'young (of birds)' (VEWT 96; Menges, 1979: 179) and, I will here add, the hitherto non-discussed cognate of Yakut ča yar 'family, children; maid, servant'. Çınar here fills in the interesting cognate forms of Derleme Sözlüğü dial. Turkish çağa 'child', Sivas Vilayet dial. Turkish çağa boğan 'bat (flying mammal), lit. child choker'. The Yukaghir form has undergone the assimilation of -ar- >-a:. If this suggestion is correct, and the semantics does make sense, the name of the dog is to be considered either 'family' or 'servant'.

Tentative borrowing

Proto-Turkic *čal- 'to knock down, etc.' > Yakut sālin- 'to fall abruptly' (EDAL 414), borrowed as: TY tude-čalete 'to hang oneself, lit. to abruptly fall down (of oneself)' (Nikolaeva, 2006: 122). 
The Yakut word is Turkic, cf. Proto-Turkic *čal-, with no less than fourteen meanings (EDAL 413); indeed it is suggested that at least two roots are merged in this entry, and future research will have to sort out the specifics.

\section{New Tungusic borrowings into Yukaghir}

In this section, two new borrowing suggestions into Yukaghir from Tungusic sources are described, along two tentative ones, including dialectal Tungusic data:

New borrowing

П-Т, е, н, и, с Ewenki ńōrī женский посох для езды на олене = female staff for riding a deer'

(Vasilevič, 1958: 290) (> Dolgan ńorii 'женский посох летний; Stock, den Frauen beim Rentierreiten verwenden = woman's summer walking stick (staff); female staff for riding a reindeer' (Petrov, 2015:

24: ${ }^{5}$ Stachowski, 1993: 187), borrowed as: TY nuorii ‘woman's walking stick' (Nikolaeva, 2006: 312).

This borrowing into Tundra Yukaghir is from Ewenki as clearly shown by both the phonology and semantics. There is also KY no:roka:n 'stick', which appears to be another Tungusic version, a diminutively suffixed one, of this same word, and which is a separate borrowing. There is also the Dolgan form, as given above, which can herewith be etymologized as being of Ewenki origin. It would appear as if the above short Ewenki form is the original one having been borrowed suffixed or not into several of the surrounding languages. In any case, there is no reason to reconstruct a Late Proto-Yukaghir root for these borrowed forms. The Yukaghir forms have been compared before to Proto-Samoyed *norV 'stick, staff' (SW 97-98), but this comparison is now unnecessary because there is a clear loanword etymology at hand. Care should be taken to keep the Ewenki word apart from the phonetically very similar ńōū 'hook'.

New borrowing

Mongolic čirga 'sleigh', borrowed as V. Nrc. Ewen čerga 'sleigh' (Poppe, 1972: 103) > TY sirzaa

'roughly made sledge', sirzaadie 'sledge' (Nikolaeva, 2006: 423).

\footnotetext{
5 This recently published volume is very interesting in that it presents us with an encyclopedia of reindeer-related terminology in Dolgan! Much of it has never been documented anywhere else before, and thus much of it also remains non-etymologized. The terminology found therein is no doubt mostly of Russian, Ewenki and Yakut origin, but the details remain to be sorted out. The volume will aid the etymologizing of reindeer-related terminology between Yakut, Ewen, Ewenki, Yukaghir, Russian and possibly also the Samoyedic languages.
} 


\section{ग(৫)}

A Mongolic word for sleigh has for some reason been borrowed into Tundra Yukaghir, albeit with narrowed semantics; a roughly made sledge may be considered somewhat inferior to a standard, sturdy sledge, and may have been the result of hasty improvisation adapting to a particular weather situation or an emergency need. In any case, this time the Mongolic borrowing has reached Yukaghir through an Ewen dialect as an intermittent language. This word is found as čarga 'sled, sleigh' in modern Mongolian. In classical Mongolian the word was tchirga (сани, нарты = sled, sleigh' (Kowalewski, 1849: 2187), so this is assuredly an old Mongolic word, proving the direction of the borrowing. B. Brosig suggests as valid, but possibly irregular, source Proto-Mongolic *cïri- 'to pull, drag' (Nugteren, 2011: 304) with the word at hand being a suffixed form.

Interestingly, the EDAL speculates that Manchu sežen 'carriage' has been borrowed into many other Tungusic languages (such as Nanai sežẽ, Ulcha sežen; TMS 2 137), and originated in *sir-gen (< Proto-Tungusic * siru- 'to rotate, to roll, to glide'; TMS 2 96-97). Now, Tungusic *sirgen 'carriage', constructed only on the basis of Manchu, is close to Mongolic *črga 'sleigh', and there appears to be a connection. I consider the Manchu form to be a suffixed (Pre-Proto-)Mongolic or Para-Mongolic borrowing. However, as this early hypothetical Tungusic form is no longer attested anywhere, but the Mongolic form is, we must posit the borrowing chain of Mongolic > Ewen > Yukaghir.

Tentative borrowing

Proto-Tungusic *čime 'вершина (дерева, горы); темя = top (of tree, mountain); crown, sinciput' > Ewenki čime 'top'; Ewen čеm 'конец ветки, верхушка дерева = end of branch, treetop', ?čemelken 'сначала = at first' (Robbek \& Robbek, 2005: 337); Nanai čimčikë 'crown, sinciput' (TMS 2 395), borrowed as: PY *čeme- > KY čemej- 'to come to the end'; KK t'emej-; KJ čemei-, čečei-; KD čemei-; KY čemerej- ‘to end, to terminate (TR)'; KK t'emerej-; KJ čemerei-; KD čemerei-; KJ čameče- 'ready'.

The match is perfect phonologically, but uncertain semantically. We may assume 'end of something' (Ewen) > 'to come to an end' (Yukaghir) if the borrowing suggestion from Ewen into Yukaghir is correct.

Tentative borrowing

Ewenki semni-mī 'заблудиться (о человеке) = to get lost (of a man)' > TY semnejuol 'place where many people died because of an accident or epidemic', semnel 'name of a river' (Nikolaeva, 2006: 427).

The Ewenki verb for 'to get lost' is not attested in any other Tungusic language, and it is therefore quite likely a borrowing in itself. The Tundra 
Yukaghir form, then, appears to be based on this root, where the ending -juol literally means 'site', cf. TY sald'ijuol 'site of a split', sald'i- 'broken' (Nikolaeva, 2006: 411). Thus, the rendered meaning of semnejuol would literally be 'place of getting lost, site of man loss, place of destruction', which appears to be a fairly accurate way of describing the 'place of an epidemic'. The river name of semnel is also found elsewhere as lajuolel-semnel, a lake name, which literally means 'the last place where many people died' (Nikolaeva, 2006: 231). The phonological correspondence is also accurate, but due to the lack of attested forms in other languages for comparisons, this is a tentative suggestion at best. The river, semnel, has previously been etymologized (Kurilov, 1997: 31) as connected to a word semnel 'разрушенный, приземистый, низкий = destroyed, ruined; squat, low', and while the comparison is accurate, the word is missing from Kurilov's dictionary (2001: 454); therein, a connection between semnel and seme 'берег = coast', but that seems unrelated. Instead, my comparison with the Tungusic form has not been mentioned before.

\section{Additional data}

Proto-Mongolic *gajika- 'удивляться = to wonder, marvel' (EDAL 527) > Written Mongolian zajiqa- 'удивляться = to be surprised, to marvel', yajiqal 'strange, queer, quaint; astonishment, wonder; miracle, prodigy, spectacle, show; odd fellow; that one (when the name of the referent is to be avoided)' etc. (Lessing, 1960: 345) > Ewenki gajka- gajkān-mĩ gajkāndemī 'удивляться, поражаться = to wonder, to marvel', etc. (Vasilevič, 1958: 81; Bolbyrev, 1994: 457; TMS 1 136) > TK qajzalne- 'famous' (Nikolaeva, 2006: 375).

The Mongolic root is borrowed not only into Ewenki, but also into Solon, Udege, Nanai and Manchu (but not into Ewen), as per the TMS, and the root likely entered Yukaghir through Ewenki. The modern Mongolian verb is zaŭxax (gaikhakh) 'to marvel'. The Yukaghir form was suffixed after borrowing, seemingly with ${ }^{*}-l$-, a nominal derivational suffix, and ${ }^{*}$-ńz-, a proprietive suffix (Nikolaeva, 2006: 81-82), i.e. *qaj子a-l-ńa- 'to be a wonder, to be a marvel' > qajzalné '(to be) famous', because indeed, semantically, something 'marvelous' can easily also equate to something 'famous'. The phonology is a good match, and another similar Mongolic borrowing would consist of Written Mongolian yalayun 'goose', borrowed as SD galijan 'a woman in a tale, lit. goose' (Piispanen, 2016: 267), with 


\section{J(e)}

an apparent metathesis. J. Bäcker suggests that the Written Mongolian form could be a Chinese borrowing, cf. Chinese 怪 guai 'strange, amazing, surprising, awkward', and if correct would mean that we have an ultimately Chinese loanword etymology for a Yukaghir root.

\section{New Russian borrowings into Yukaghir}

In this section, three new borrowing suggestions into Yukaghir from Russian sources are described:

New borrowing

Russian mylo ('miłə) ‘мыло = soap', borrowed as: TY myyle ‘мыло = soap' (Kurilov, 2001: 304, 436, 459).

The word for the trading commodity of 'soap' was naturally also borrowed into Yukaghir, and then seemingly directly from Russian. Because the Yukaghir form is pronounced exactly as the Russian form, phoneme by phoneme, we may assume borrowing between them, even though the Russian form has also been borrowed into other neighboring languages in very similar shapes; cf. the congeners Yakut myyla (JRS 247); Ewen miile myyle (Robbek \& Robbek, 2005: 167); Ewenki myle (Vasilevič, 1958: 267). The Yukaghir word is not to be found in any dictionary entry, but rather in inflected or non-inflected form in three different example texts in Kurilov, 2001 on pages 304, 436, and 459.

New borrowing

Russian ustat' (v'stati) 'устать = to get tired', borrowed as: TY uttej- 'to get tired', utteluu- 'tiring', utte-

gewre- 'to have a rest; to die (lit. to carry away tiredness)', etc. (Nikolaeva, 2006: 446).

It would seem as if the Tundra Yukaghir verb for 'to get tired' is borrowed directly from Russian. The semantics are identical and the phonological reasoning is as follows (with aid by M. Zhivlov): Old Russian loanwords in Kolyma Yukaghir systematically substitute Russian /s/ with Kolyma Yukaghir /č/. Examples include: KY čereuro: 'silver', borrowed from Russian cepeбpo (serebro) 'silver'. While not evident in TY data, if we assume a similar substitution also therein, then we would have the perfect explanation for the /tt/ of this word. There is a (morpho)phonological process, which turns /č/ to /t/ before consonants in TY (for example: TY peč- 'to trot (INTR) > pettes- 'to trot (TR)'). Thus the Yukaghir geminate -tt- would be the result of /čt/ </st/, and the vowel change $-a^{-}>\left(-\partial^{-}>\right)-e$ - is prosodically driven and expected. 
New borrowing

Russian kl'uka (клюка́) ‘палка, посох, (dial.) палка с загнутым концом, которой бьют шар при игре в клюшки = stick, staff; stick with a curved end, which is used to hit a ball when playing with clubs', borrowed as: TY kul'ikaa-amun 'spherical ends of the shin-bone' (Nikolaeva, 2006: 226).

The literal meaning of the Yukaghir compound is 'latch bone', which may be an apt name for describing the end parts of the shin-bone aka. the tibia. of course, the bone looks like a club at the end, and this is important for the comparison with the meaning of the Russian dialectal word. This dial. Rus. borrowing (suggested by A. Savelyev) is only found limited to a form of Tundra Yukaghir. Phonologically, in Yukaghir, the cluster $k l$ - has been expectedly broken up by epenthesis, the stressed final vowel, á, could easily produce the long -aa with prosodic adjustment, while the palatal -l'u-finds a counterpart in Yukaghir -l'i-. As both Zhivlov and Savelyev note, the same Russian word has also been borrowed as Buryat külikaa 'poker', Middle Chulym kulükka 'poker', as well as forms in Yakut and Teleut (Anikin, 2003: 270).

\section{A Yukaghir borrowing in Ewenki}

In the old materials of Billings (Sauer, 1802) we find the Old Yukaghir form of B kelenni 'red'. This is of course related to KY kejlań- 'red', ke:lo:- 'dry', etc. (Nikolaeva, 2006: 204) and the word is etymologically of well-attested Yukaghir origin. However, the same Billings materials also has Ewenki koolani 'red'; this appears to be a relatively rare Yukaghir borrowing because there already exists an Ewenki variants of Tungusic etymology for 'red', namely ulama xolama xulama 'red' (Vasilevič, 1958: 436, 485, 492) (< *pula 'red'; TMS 2 343-344). The development of $* p$ - > Ewenki $x$ - is common and expected, and it well explains the other standard Ewenki and dialectal forms, but the word-initial $k$ - and word-final -ni (instead of $-m a$ ) instead reveals this to be of possible Yukaghir origin. Yukaghir comparanda of interest include BO kólene 'red', KL kejlanii 'red', ME kelenni, MK kéeleni kólani 'red; yellow', this last form being particularly interesting because it is practically identical with the Ewenki form and so we can here posit and suggest a somewhat rare Yukaghir borrowing in (dialectal?) Ewenki. 


\section{ग(๑)}

\section{Some further Yukaghir etymological considerations}

The Tungusic root *iče- 'to see' (EDAL 579) is already known borrowed into Tundra Yukaghir (Nikolaeva, 2006: 460) with the base meaning 'to see; to look, to watch' as well as 'seer, prophet'. However, in Sauer's materials from Billings expedition (Sauer, 1802), he notes B itschel 'shephard', itschell 'guard', and the literal meaning of the "Sauer" Yukaghir must be 'watcher' because $-l$ is a common nominal derivational suffix. Of course, a 'shepherd' is somebody who watches the herd among other things, and watching is a guard's main duty. The borrowing appears to be independently made from the one into Tundra Yukaghir, so we can summarize this Tungusic root as having been borrowed into both TY, and B.

The last part of TY (qajčie-)lačin-meruu 'ritualistic name for fire' appears to be etymologically unclear (Nikolaeva, 2006: 266, 374). Its meaning, however, is found in Jochelson's documentation and so the full compound can be segmented as TY qajčie 'bear; grandfather' + lačil 'fire' (-l > -n for genitive) + meruu 'to sound, to become audible' (Jochelson, 1926:323). A proper translation might thus be 'the sound of ancestors' fire' or similar.

SD šon-conmigi 'пила = saw' (Spiridonov, 2003) has thus far not been etymologized, but it is clearly related to TY saan-d'awnii 'saw'. The first part of the compound means 'tree' (Nikolaeva, 2006: 392), while the second part means 'to cut' (Nikolaeva, 2006: 136). The SD compound is thus fully of Yukaghir etymology.

SD samajaj- 'стучащий = knocking' (Spiridonov, 2003) has hesitantly been connected to the PY root *sapa- 'to hit' (Nikolaeva, 2006: 396) - which, I note, is cognate with Proto-Uralic *čappa- 'to hit, to beat' (UEW 29) - but this dialectal Yukaghir form could, however, instead be another irregular Ewenki borrowing, cf. čalamdaj 'биться, мотаться, бить, лягать ногами (о животных); стучать, колотиться (о сердце) = to beat, to kick (of animals); to knock, to beat (of heart)' (Robbek \& Robbek, 2005: 327). In other words, this particular SD word appears to be an Ewenki borrowing, in contrast to other similar Yukaghir words which are of (Uralo-)Yukaghir etymology.

The Yakut word uot 'fire, heat, flame; light, ray of sunshine or moonlight' has been suggested the origin of borrowed KY ottu: otul 'place where fire is made; 
camp; smb's hunting or fishing place'; SD uot; KY ottu:(ńa:)nuba 'place where fire is usually made', ottuu 'fire-place', otu 'bonfire'; otuga ammalnuj 'campfire' (Piispanen, 2019b: 61). A case may be made, however, for some of these words having been semantically contaminated or lexically borrowed from Yakut ot $\bar{u}$ 'tent', which is also of Turkic origin (EDAL 1069). The Yakut words for 'tent' and 'fire' are, after all phonetically very similar, and by combining the meanings of 'tent' and 'fire' we do have 'a place where fire is usually made; camp', and 'smb'd hunting or fishing place'.

As is known, Tundra Yukaghir has borrowed the word for 'school' as škola iskuola iskuole (Nikolaeva, 2006: 405; Atlasov \& Kurilov, 1992; Kurilov, 2001: 100) from Russian. ${ }^{6}$ However, Tundra Yukaghir also uses a synonymous uraanube 'школа = school' (Atlasov \& Kurilov, 1992; Atlasova, 2007: 140), which to the best of my knowledge has not been discussed before. The word literally means 'learning place' and is, of course, another Yakut borrowing, cf. üörän- 'to learn' (TMS 2 23), responsible also for TY uraa- 'to learn, to study', uruul 'belief', uraričiiče 'teacher', etc. (borrowing noted in Nikolaeva, 2006: 444-445). Yakut borrowing for these latter Yukaghir words were hesitantly given by Nikolaeva, but there should be no doubt about it despite the Yakut word being used differently semantically.

There is a very obviously borrowed name in KY dubegləš 'a man in folklore' (Nikolaeva, 2006), however it is not at all clear wherefrom. I conjecture that this could actually be the name Douglas. In Yukaghir, the change $w>b$ is known, and if the name was pronounced anything like /'d $\Lambda$ wglas/, it would very naturally, along epenthesis of consonant clusters, have become dubeglaš in KY. If correct, the name would describe some early visiting explorer or researcher, but I know of no one fitting in the history of Siberian explorations. Therefore, this opaque name borrowing could instead refer to a folklore tale as told by some neighboring tribe as suggested, for example, by the voiced plosives.

An old word for 'white' is attested as MC pocinyj 'white' and BO pecínij (Nikolaeva, 2006: 345). To this can be added B po-innei 'white' (Sauer, 1802).

6 Despite the similarity, Yakut oskuola 'school' (JRS 279), as evident by the phonology, is an independent Russian borrowing, and not one of the Russian cultural words intermediated by Yakut into Yukaghir (such as those in Piispanen, 2018c). 
Despite the missing affricate, this obviously etymologically belongs with the others. Beyond these words, this color word is not attested in later forms of Yukaghir, and its origin is unknown. Perhaps it is comparable to Proto-FinnoUgric *pečV 'frost, dew', since this is indeed colored 'white', but the comparison is not to satisfaction.

The attested, old word B onmanneig 'wife' (Sauer, 1802), unmentioned in any of my sources, is identical to B onmanneig 'clever', KY önməni 'clever', etc. (Nikolaeva, 2006: 333). This suggests that the B word for 'wife' really originates in the word for 'clever'. Perhaps the meaning arose from the idea that the wife should be directing the head of the husband, and as such she is a clever advisor, although this is a Christian tenet and not very likely at all. Another option is that this is a scribal error in the meaning of the Sauer word, and that the word originally meant 'clever' there as well and nothing else.

SD agzakelge 'name of a river' has been given a PY reconstruction ( ${ }^{*}$ ayča- in Nikolaeva, 2006: 96), but this is wholly unnecessary because the SD word is to be constructed as from *way-ča-kel-ga, lit. bridge of the nose. This can be deduced from a number of facts: in SD are known the words angza 'eye', angci- 'to look for', and angzad-oži 'tears, lit. eye water', and similarly, there is a river named and'ekel-in KJ, which also means 'bridge of the nose', and which is practically the same name as the SD river name.

KD ayčil 'inheritance; investigation' is of course related to TY wayčid'aaje 'seeker; beggar' and TD onči- 'to inherit'; ončim 'inheritance' and so the hesitantly reconstructed root of PY *on- (Nikolaeva, 2006: 329), including the TD words, is not at all warranted. Rather, the meanings and phonological form of all of these words suggest that they all are derivatives of *way- *won-(-čə-) from where words meaning 'eye', 'to look for', etc. have arisen (Nikolaeva, 2006: 452). Indeed, we would have expected retention of the ${ }^{*} w$ - in the TD form but it is for some reason irregular. Further, the $-n$ - instead of $-\eta$ - in onči- is also irregular. Further, upon addition of the nominal derivational suffix $-l$, the preceding schwa, - -2 , regularly becomes an -i-. In TD oyčim the ending is $-m$, but as that would be a Tundra Yukaghir suffix marking an adverbial ablative, which makes no sense here, I suspect that this is erroneously recorded and should also simply be opčil. 


\section{Ј(৫)}

In a recent paper by M. Zhivlov (2019), named Areal polysemy 'earth/year' in North American languages: historical implications, he discusses the polysemous use of words meaning 'earth/year' in numerous languages. The suggested semantic development given at the end of the paper is sound (with 'turn earth' > 'seasons' > 'year'), and the meaning is suggested to have spread through contacts ("semantic borrowing", possibly through folklore). Now, I wish to point to other non-North American languages where the polysemous use also exist, namely Tundra Yukaghir sukun, -rukun, -dukun (phonological variants of compounds) 'clothes, thing; nature, earth, world; sky, year, age, life', with very similar meanings in TJ šukun- (the š- suggests borrowing here), TD sukun-, -rekun, -rikun. The meanings are more limited in other Yukaghir languages, cf. KY šuku: 'hand-made object; $\mathrm{KJ}$ šuku 'earth'; KD čukun 'everything'; MU tschukú 'sky', but these too all appear connected and very likely the documented meanings are incomplete in most of these. It is difficult to see how the etymological connection between all of these could have arisen, except through a scheme similar to what Zhivlov presented for North American languages. Otherwise, 'sun' and 'year' can be semantically connected, as suggested by J. Bäcker, through sunrises and sunsets taking place on a circle around the Earth with one full circle being completed within a year, such as in Korean hae (해) 'year; sun'. I believe that the various Yukaghir meanings may have arisen through a scheme partly parallel to the one in North America, along additional tertiary semantic changes and developments. Indeed, Zhivlov also suggests in private correspondence that the Yukaghir word sukun has a slightly different semantic history than the Native American words he discussed; he agreeably believes that the original meaning was 'thing', which produced 'clothes' and on the other hand 'the subject of various weather-verbs' and from there 'nature, earth, sky, etc.', and seemingly also 'year' (see below). The Yukaghir polysemy is very likely independently arisen from the one found in the North American languages. Further, I note that the Late Proto-Yukaghir root *suk- (Nikolaeva, 2006: 418-419), where the above words are mentioned, clearly consists of materials from at least three different roots, which should be cleared up in the future.

Important for the suggestion above is that there are also other, but similar, methods for constructing the meaning of 'year' in Yukaghir: TY sukun-molyal 'year; age, lit. nature's joint'; MK tschukún-málgal, is a different and non-related 


\section{ग(๑)}

innovation, which is also seen in non-discussed BO polin-molgon 'year, lit. many joints'. In this metaphorical scheme a 'joint' appears to symbolize a 'month', or perhaps 'season', which is a different way to construct the meaning of 'year', cf. 'many joints, nature's joints' > 'many months/seasons' > 'year'. In fact, since the BO compound means 'year' in the singular, and not 'years', this is the only possible interpretation of development, and semantically it mirrors part of the development in the North American languages.

I know of no other northeast Siberian language where the polysemy 'earth; year' is evident, and it would therefore seem as if it has arisen as a hapax legomenon in Yukaghir only. It could be worth it, though, to check if it exists in some manner also in the Yup'ik languages, and in Chukchi. All of this could perhaps suggest that the development is not entirely unforeseen in the world's languages, and that the meaning could have arisen independently in a few remote languages where it also exists.

\section{Documentation correction}

In bibliographic and etymological research we are of course wholly dependent on the quality and quantity of the field data to be used. It is therefore of utmost important that the data be as accurate and correct as possible. I am myself currently engaged in the collecting of additional Tundra Yukaghir lexical field data, and am becoming increasingly aware of the various pitfalls in data documentation. Any and all transcribed data must be proof-read and evaluated as to the correctness of the noted forms and orthography. All incorrect notes must be corrected before any wrongful conclusions are drawn from it, or before the wrong form is referenced in future scientific publications. In these sections in the paper series, I usually correct wrongfully documented forms based on various factors.

First, the attested, old word B tindij 'look' (Sauer, 1802) - thus far unmentioned in most sources - belongs semantically and etymologically with $\mathrm{KY}$ tindi: 'here' and SD tindi (Nikolaeva, 2006: 430). The connection between 'look' and 'here' is fairly obvious, and Billing's word must be a pointed 'here' taken as meaning 'look'.

Second, in the entry of PY *woyo 'face' (Nikolaeva, 2006: 457) we have representatives of Tundra Yukaghir and its dialects but, oddly enough, only the 


\section{J(৫)}

Omok derivatives meaning 'forehead' and 'head' are included, while the basic word MO woyo 'face' (Wrangel, 1841: 116) is missing altogether and which should be added to these comparisons as well.

Third, in Nikolaeva (2006: 435), with the reconstruction of PY *tönpə- 'to be strong', we find B tonbay, but, checking the original spelling (Sauer, 1802) the "Billings" Yukaghir form is actually tonboy 'strength' instead.

Fourth, Old Yukaghir MC ńaimagen 'elk', tentatively, but needlessly, reconstructed with its own Late Proto-Yukaghir root in Nikolaeva, 2006: 286 is no doubt etymologically connected to KY ńanmə 'shrubbery'. The old documentation is not orthographically very accurately described, but the similarity is forthcoming, and, indeed, the same $\mathrm{KY}$ word is also used to describe elks like KY nanmo-legut-ejrajban 'elk, lit. the one who walks eating willows', so indeed there is semantic precedent to connect a willow bush with elks who eat them. The only thing unclear in the MC word is the ending -gen, but this actually looks like the Tungusic -ka:n, which is a diminutive suffix and part of many animal names (i.e. ńaimagen ?< *nanmə-ka:n).

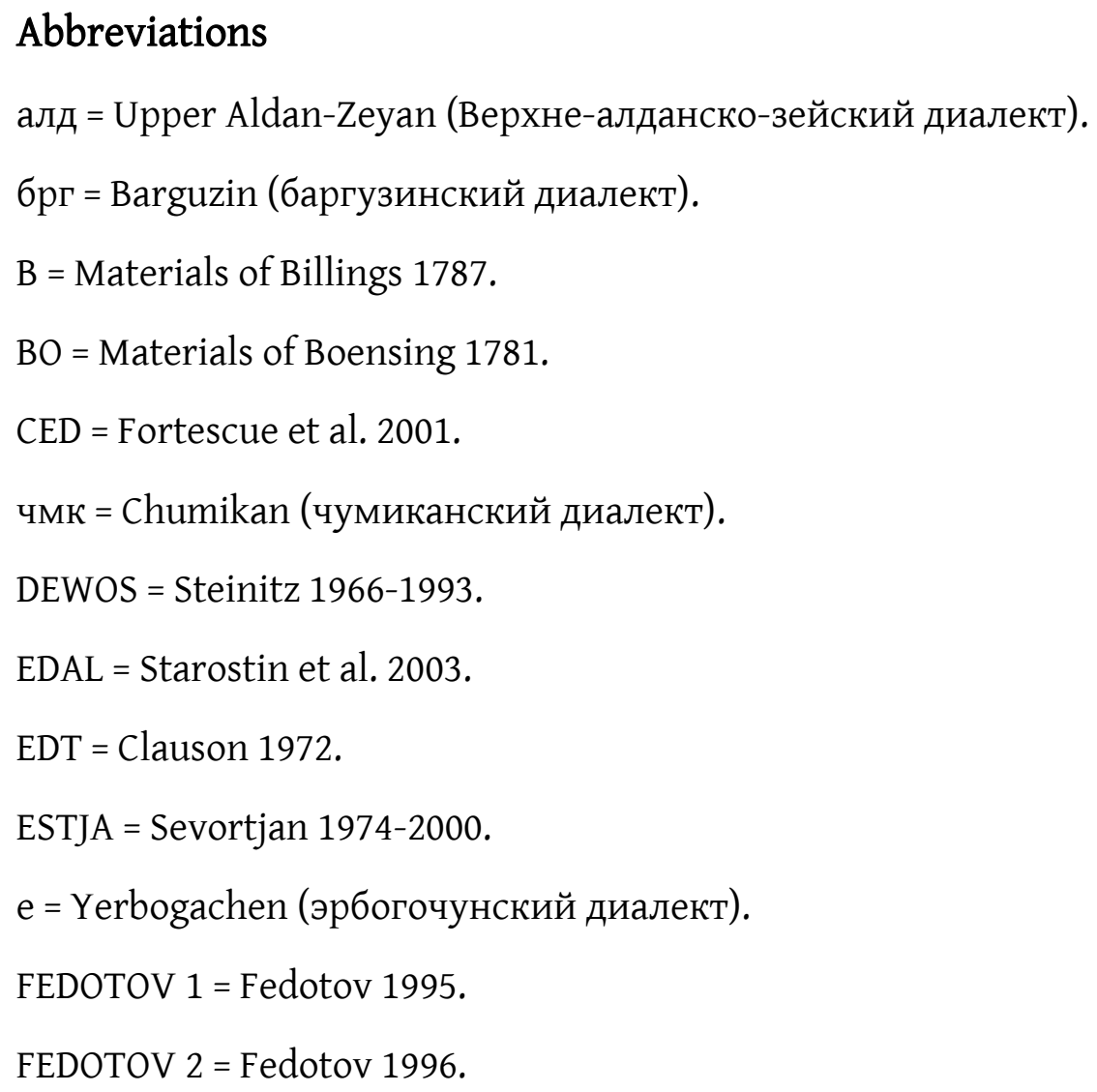




\section{J(ఠ)}

JLTT = Martin 1987.

JRS = Slepcov 1972

и = Ilimpi (илимпийский диалект).

$\mathrm{KD}=$ Kolyma Yukaghir from Jochelson's manuscript dictionary.

KJ = Kolyma Yukaghir materials of Jochelson 1898 and 1900.

KK = Kolyma Yukaghir materials of Krejnovič 1982.

$\mathrm{KL}=$ Materials of Klitschka 1781.

KW = Ramstedt 1935.

$\mathrm{KY}=$ Modern Kolyma Yukaghir .

Leksika = Tenišev 1997.

м = Mai (майский говор).

$\mathrm{M}=$ Materials by Maydell presented by Schiefner 1871a and 1871b.

MC = Chuvan materials of Matjuškin in Wrangel 1841.

$\mathrm{ME}=$ Materials of Merk 1787.

MGCD = Menggu yuzu yuyen cidien, Qinghai, 1990.

MK = Kolyma Yukaghir materials of Mueller and Lindenau in 1741.

$\mathrm{MO}=$ Omok materials of Matjuškin in Wrangel 1841.

MU = Ust'-Janskoe materials of Mueller/Lindenau 1741.

н = Nepa (непский диалект).

орч = Orochon (говор орочонский эвенков).

П-Т = Podkamen (подкаменно-тунгусский диалект и его говори).

RS = Materials of Rajskij and Stubendorf presented by Schiefner 1871a.

SD = Kolyma Yukaghir materials of Spiridonov 2003.

$\mathrm{SU}=$ Materials by Suvorov presented by Schiefner 1871a.

c = Sumy (сумский диалект).

c-б = Northern Baikal (северобайкальский диалект).

cx = Sakhalin (сахалинский диалект).

тк = Tokko (токкинский говор). 


\section{ग(ब)}

TMT = Tommot (томмотский говор).

Тнг = Tungir form of the Vitim-Olekminsky dialect (Тунгирский говор витимоолекминского диалекта).

TT $=$ Totti (тоттинский говор).

$\mathrm{TD}=$ Tundra Yukaghir materials of Jochelson 1926.

TK = Tundra Yukaghir materials of Krejnovič 1958 and Krejnovič 1982.

TMS 1 = Cincius 1975 .

TMS 2 = Cincius 1977 .

$\mathrm{TY}=$ Modern Tundra Yukaghir.

урм = Urmi (урмийский говор буреинско-урмийско-амгунского диалекта).

учр = Uchur-Zeya (учурско-зейский диалект).

UEW = Rédei 1988-1991.

VEWT = Räsänen 1969.

з = Upper Aldan-Zeyan (зейский говор верхнёалданско-зейского диалекта).

\section{References}

Atlasov, J. I. \& Kurilov, G. N. (1992). Russko-jukagirskij razgovornik. Jakutsk: Rozovaja cajka.

Atlasova, E. S. (2007). Slovar' jukagirsko-russkij i russko-jukagirskij (tundrenyj dialekti) - okolo 3500 slov. St. Petersburg: Filial izdatel'stva prosveshchenije.

Bazin, L. (1963). Über die Sternkunde in alttürkischer Zeit. Akademie der Wissenschaften und der Literatur. Abhandlungen der Geistes- und Sozialwissenschaftlichen Klasse 5. Wiesbaden, 571-582.

Cincius, V. I. (1975). Sravnitel'nyj Slovar' Tunguso-Man'žurskix Jazykov I. Leningrad: Akademia Nauka.

Cincius, V. I. (1977). Sravnitel'nyj Slovar' Tunguso-Man'žurskix Jazykov II. Leningrad: Akademia Nauka.

Fedotov, M. R. (1996). Ėtimologičeskij slovar' čuvaškogo jazyka II: Sav-Yaštaka. Čeboksary: Čuvaškij gosudarstvennyj institut gumanitarnyx nauk.

Jochelson, W. (1908). The Koryak Religion and Myths. Memoir of the American Museum of Natural History VI. New York \& Leiden: E. J. Brill. 
Jochelson, W. (1926). The Yukaghir and the Yukaghirized Tungus. New York: G. E. Stechert American Agents.

Kowalewski, J. É. (1849). Mongol'sko-russko-frantsuzkij slovar' III (Dictionnaire MongolRusse-Français III). Kazan: Imprimerie de l'université.

Kurilov, G. N. (2001). Jukagirsko-russkij slovar'. Novosibirsk: Rossiskaja Akademija Nauk.

Nikolaeva, I. (2006). A Historical Dictionary of Yukaghir. Berlin \& New York: Moutonde Gruyter

Nugteren, H. (2011). Mongolic phonology and the Qinghai-Gansu Languages. Utrecht: LOT.

Pekarsky, E. K. (1959). Slovar jakutskogo jazyka I-III. Yakutsk: Akademija Nauk SSSR.

Petrov, A. A. (2015). Olenevodčeskaja leksika dolganskogo jazyka, etnolingvističeskij slovar': učebnoje posobije. St. Petersburg: Almaz-Graf.

Piispanen, P. S. (2013). The Urali-Yukaghiric connection revisited: Sound Correspondences of Geminate Clusters. Suomalais-Ugrilaisen Seuran Aikakauskirja, 94, 165-197.

Piispanen, P. (2018a). Additional Turkic and Tungusic borrowings into Yukaghir. Turkic Languages, 22(1), 107-137.

Piispanen, P. (2019). Additional Turkic and Tungusic borrowings into Yukaghir II. Journal of Old Turkic Studies, 3(1), 54-82.

Piispanen, P. (2019b). Additional Turkic and Tungusic borrowings into Yukaghir III. Journal of Old Turkic Studies, 3(2), 321-371.

Piispanen, P. (2019c). Re-etymologizing Russian cultural vocabulary in Yukaghir as mediated by the Yakut. Turkic Languages, 23(2), 222-249.

Piispanen, P. (2020a). Additional Turkic and Tungusic borrowings into Yukaghir IV. Journal of Old Turkic Studies, 4(1), 152-187.

Piispanen, P. (2020b). Additional Turkic and Tungusic borrowings into Yukaghir V. Journal of Old Turkic Studies, 4(2), 469-498.

Räsänen, M. (1969). Versuch eines etymologischen Wörterbuchs der Türksprachen. Helsinki: Suomalais-Ugrilainen Seura.

Robbek, V. A. \& Robbek, M. E. (2005). Evensko-Russkij slovar'. Novosibirsk: Nauka. 


\section{0}

Sauer, M. (1802). An Account of a Geographic and Astronomical Expedition to the Northern Parts of Russia. For ascertaining the degrees of latitude and longitude of the mouth of the river Kovima; of the whole coast of the Tshutski, to East Cape; and of the islands in the Eastern Ocean, stretching to the American Coast. London: A. Strahan.

Şirin-User, H. (2014). Čolpan 'The Planet Venus' in Turkic. Studia Etymologica Cracoviensia, 19, 169-178.

Slepcov, P. (1972). Jakutsko-russkij slovar'. Moscow: Sovetskaja Ensiklopedija.

Spiridonov, N. I. (2003). Jukagirsko-russkij slovar' i évensko-russkij slovar'. Jakutsk: Yakut State University Publishing House.

Stachowski, M. (1993). Dolganischer Wortschatz. Kraków: Uniwersytet Jagiellónski Kraków.

Starostin, S. et al. (2003). An Etymological Dictionary of Altaic Languages I-III. Leiden: Brill.

Ugarova, G. S. (1993). Russko-Yakutskij slovar' biologičeskij terminov. Yakutsk: MO RA.

Vasilevič, G. M. (1958). Evenkijsko-Russkij Slovar'. Moskva: Gosudarstvennoje isdatel'stvo inostrannyx i natsional'nyx slovarej.

Wrangel, F. von (1841). Putešestvie po severnym beregatn Sibiri i po Ledovitomumorju, soveršennoe v 1820, 1821, 1822, 1823 i 1824 godax ekspediciju, sostojav šeju pod načal'stvom flota lejtenanta Ferdinanda fon Vrangelja I-II. St. Petersburg.

Yegorov, V. G. (1964). Etimologičeskij slovar' čuvashkogo jazyka. Cheboksary.

Zhivlov, M. (2019). Areal polysemy 'earth/year' in North American languages: historical implications. Etnografia, 3(5), 167-180. 